\title{
Visible lipaemia in a man with early onset metabolic syndrome
}

\author{
Luke Debenham 이 , Jayashekara Acharya
}

Department of Endocrinology, County Hospital Hereford, Hereford, UK

Correspondence to Luke Debenham: LXD524@student.bham.ac.uk

Accepted 7 July 2020

\section{DESCRIPTION}

A 27-year-old man of Indian descent who is $174 \mathrm{~cm}$ tall, weighed $85 \mathrm{~kg}$, with a body mass index of $29 \mathrm{~kg}$ $\mathrm{m}^{2}$ presented with polyuria, polydipsia, dyslipidaemia, hyperglycaemia and ketonuria. He has a family history of type 2 diabetes and drinks around one unit of alcohol a week. On clinical examination, there were no eruptive xanthomas or corneal arcus and retinal examination was not undertaken. His blood results showed random triglycerides $87.4 \mathrm{mmol} / \mathrm{L}$ and glycated haemoglobin $134 \mathrm{mmol} /$ mol.

After initial phlebotomy, a lipid layer in his blood began to noticeably separate after half an hour and visible lipaemia reached maximum extent after 4 hours without centrifugation (figure 1 ). The rate of blood flow was normal.

This man recounts weighing $105 \mathrm{~kg} 2$ years ago; since then, he has lost weight with the aim of

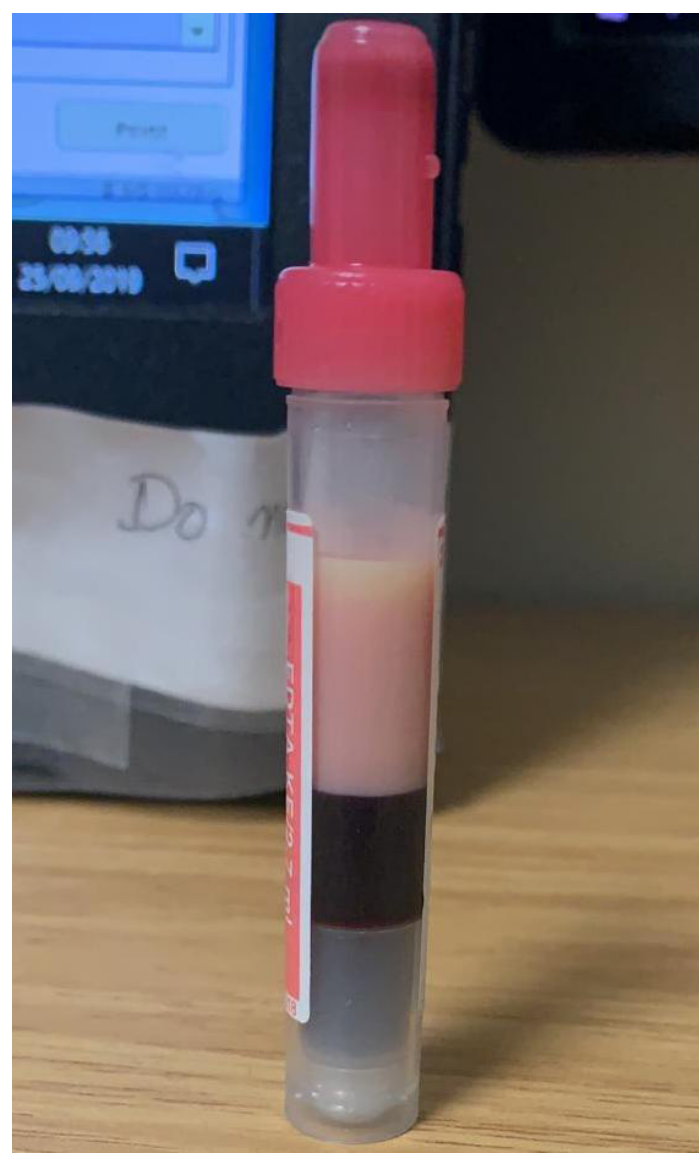

Figure 1 Blood drawn at first presentation to accident and emergency, left to rest for 4 hours before centrifugation showing visible lipaemia.
Learning points

- Uncommonly, dyslipidaemia can be seen as a lipid layer in blood without centrifugation. Showing this to a patient can be a powerful tool in encouraging beneficial lifestyle changes.

- Social factors such as work arrangements have an essential role in maintaining a healthy lifestyle. This man's work arrangements limited his exercise and worsened his diet. Once these were addressed, profound dyslipidaemia improved.

- Increasingly diabetogenic lifestyles cause type 2 diabetes in the young. This often presents with features more typically associated with type 1 diabetes. In this case, the patient presented with early onset hyperglycaemia and ketonuria.

meeting weight restrictions required for tug-of-war competition. He did this by cooking for himself, increasing vegetable consumption, reducing fat consumption, portion restriction and by going on four 30-minute moderate intensity runs a week. Although successful in reducing his weight, he started working in shifts requiring long commutes last year. This has led him to regularly replace meals with sugary sweets and drinks (six per day), eat more take-away food and exercise less often.

$\mathrm{He}$ was diagnosed with metabolic syndrome and advised to reduce carbohydrate and sugar intake. He was prescribed $500 \mathrm{mg}$ of metformin for 1 week and then $500 \mathrm{mg}$ two times per day. Although metformin may have some lipid modulatory effects, ${ }^{1}$ he was not started on a specific lipid modifying treatment because the patient wanted to trial lifestyle modifications first.

Lifestyle counselling and the shock of seeing the lipid content of his blood (figure 1) motivated him to modify his lifestyle. He re-commenced regular running and eliminated ready meal and sugary drink consumption. Four months later, he weighed $88 \mathrm{~kg}$, had a random triglyceride level of $9 \mathrm{mmol} / \mathrm{L}$, his blood had no visible lipid supernatant and had a random glucose of $13 \mathrm{mmol} / \mathrm{L}$.

Acknowledgements The authors would like to thanks Cecilia Hallpike for careful proof reading.

Contributors LD wrote the paper and had the idea to submit. JA reviewed the paper adding details and re-structured some of the text, gave permission to do this and leads the care for the patient.

Funding The authors have not declared a specific grant for this research from any funding agency in the public, commercial or not-for-profit sectors. 


\section{Images in...}

Competing interests None declared.

Luke Debenham http://orcid.org/0000-0002-3300-7802

Patient consent for publication Obtained.

Provenance and peer review Not commissioned; externally peer reviewed.

\section{REFERENCE}

1 Lin SH, Cheng PC, Tu ST, et al. Effect of metformin monotherapy on serum lipid profile in statin-naïve individuals with newly diagnosed type 2 diabetes mellitus: a cohort study. PeerJ 2018:6:e4578.

ORCID iD

Copyright 2020 BMJ Publishing Group. All rights reserved. For permission to reuse any of this content visit https://www.bmj.com/company/products-services/rights-and-licensing/permissions/

BMJ Case Report Fellows may re-use this article for personal use and teaching without any further permission.

Become a Fellow of BMJ Case Reports today and you can:

- Submit as many cases as you like

- Enjoy fast sympathetic peer review and rapid publication of accepted articles

Access all the published articles

- Re-use any of the published material for personal use and teaching without further permission

Customer Service

If you have any further queries about your subscription, please contact our customer services team on +44 (0) 2071111105 or via email at support@bmj.com.

Visit casereports.bmj.com for more articles like this and to become a Fellow 